
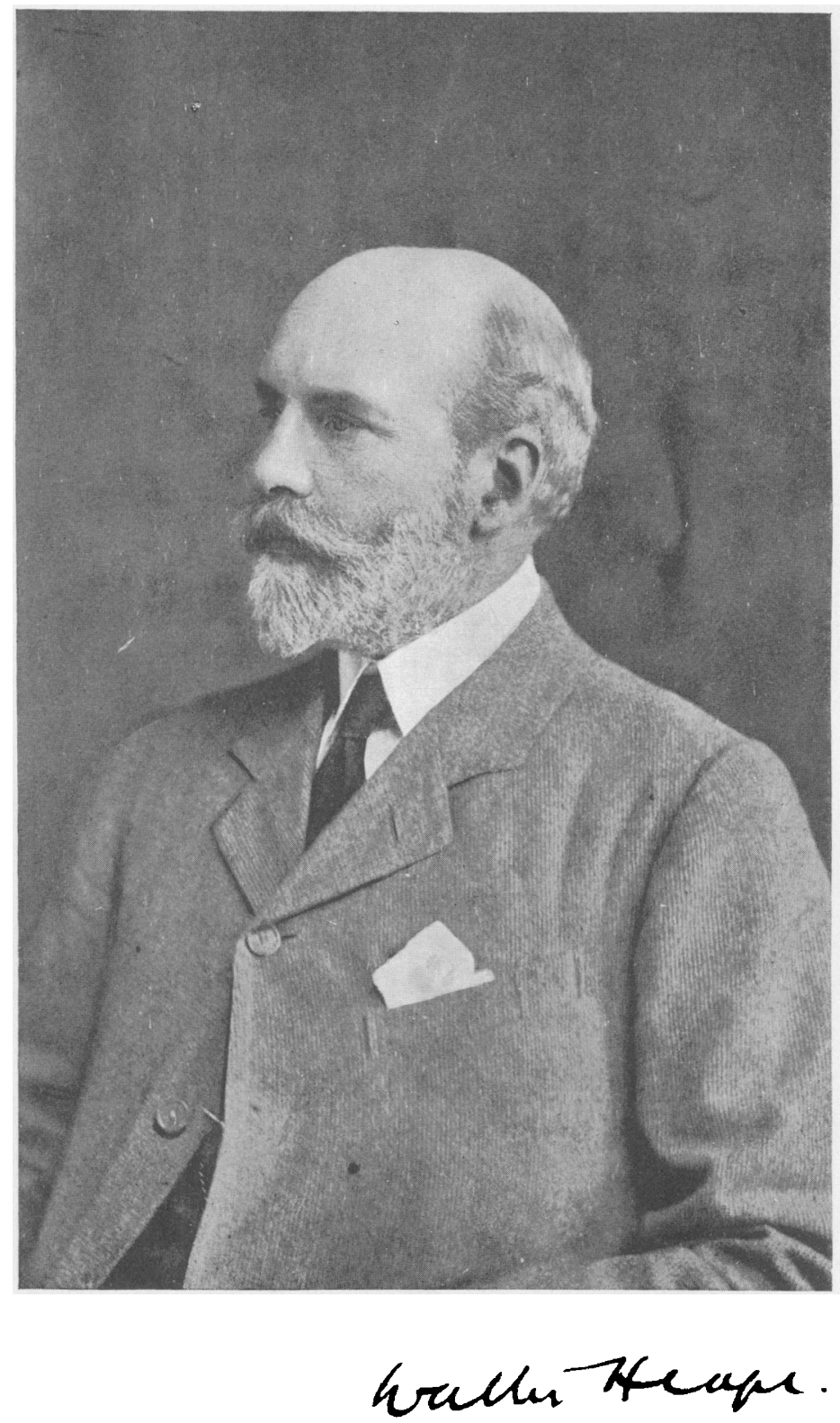

Walter Heape (1855-1929). The portrait accompanying his Obituary by F. H. A. Marshall (1930). Reproduced by permission of the Royal Society of London.

(Facing p. 1) 


\title{
An historical look at embryo transfer*
}

\author{
K. J. Betteridge $\dagger$ \\ Agriculture Canada, Animal Diseases Research Institute, P.O. Box 11300, Station H, Nepean, \\ Ontario, Canada $\mathrm{K} 2 \mathrm{H} 8 \mathrm{P} 9$
}

\section{Introduction}

If this, the International Embryo Transfer Society, were to take a 'patron saint', he would have to be Walter Heape (Plate 1), not just because he performed the first embryo transfers at the end of the last century but because of his immense influence on sciences that are fundamental to the work that we do. Although his transfer work in rabbits $(1891,1897 \mathrm{~b})$ was aimed at answering the 'pure' scientific question of whether the uterine environment influences an embryo's phenotype, and at defining the mechanisms of the supposed phenomenon of telegony, Heape's contribution to 'applied' science included the rekindling of interest in artificial insemination $(1897 \mathrm{a}, 1898)$ and the laying of a scientific foundation to the animal breeding industry with emphasis on its economic importance $(1899,1906)$. Heape's scientific heirs in reproductive physiology at Cambridge, F.H.A. Marshall and Sir John Hammond, judged (1946) his most important work to be his memoir on The Sexual Season of Mammals (1900), in which he brought together all that was then known about breeding seasons and oestrous cycles and introduced the very terms we use today in describing the phases of the cycle. Marshall (1930) also indicated Walter Heape's versatility in an obituary describing a career that included business endeavours, elephant hunting and the invention of a high-speed camera, the "Heape and Gryalls Rapid Cinema Machine", in addition to his wide-ranging biological pursuits. Marshall's own book on reproductive physiology (1910) was the first on the subject and is dedicated to Walter Heape who would have played a considerable part in forming the ideas behind Marshall's introductory statement (page 1) that "... generative physiology forms the basis of gynaecological science, and must ever bear a close relation to the study of animal breeding." The same book draws heavily on Heape's writings, including (p. 334) his 1905 postulation that oestrus depended on an interaction between a "generative ferment" and "gonadin", secreted by the generative glands. This was at a time when the first inklings of an endocrine function for the ovary had only just been gained by the gynaecologists Knauer and Halban in Vienna (see Corner, 1961), so such a prescient hypothesis, 18 years before the demonstration of ovarian oestrogen (Allen \& Doisy, 1923), would seem to deny the later assertion (Parkes, 1949) that Walter Heape regarded the ovary "merely as a producer of eggs". But it is eggs that concern us now, so let us go back to 27 April 1890 and examine what knowledge would have been at Heape's disposal when he did that first transfer. The environment of the time can be considered in relation to other major events in biology and with special regard to the history of techniques essential to embryo transfer.

* An invited lecture presented to the International Embryo Transfer Society, January 1980.

$\dagger$ Present address: Centre de Recherche en Reproduction Animale, Faculté de Médecine Vétérinaire, Université de Montréal, C.P. 5000, St-Hyacinthe, Québec, Canada, J2S 7C6. 


\section{The nineteenth and preceding centuries}

\section{The milieu of 1890}

By 1890, Darwin's Origin of Species had been published for 31 years and Mendel's Versuche über Pflanzen-Hybriden for 25 years, although the latter work was dormant, awaiting 'rediscovery' and publication in English by Bateson in 1909. Livestock improvement in Britain had been underway, empirically but successfully, for 140 years. Nevertheless, the belief that one sire could influence the progeny of subsequent sires used on the same female (telegony) was still widely held, and the results of J. Cossar Ewart's experiments that disproved the idea were not to be published for another 9 years (Marshall \& Hammond, 1946). Louis Pasteur (1822-1895) had been director of his own Institute in Paris for 1 year and 1890 was the year in which Robert Koch (1843-1910) introduced tuberculin. The founder of antiseptic and aseptic surgery, Joseph Lister (1827-1912) was professor of surgery at King's College, London.

\section{Anaesthesia, surgery and endocrinology}

Heape used chloroform to anaesthetize his rabbits, a practice that had been introduced into human medicine by Sir James Simpson in 1847, had received a boost as a result of its successful analgesic use by Queen Victoria during childbirth in 1853, and which was in quite widespread use in veterinary surgery by 1890 (Jones, 1957). In a contemporary book on Practical Farriery from the Royal Veterinary College in London, chloroform was even recommended as a treatment to prevent abortion in cattle, despite its dangers ". . . in the hands of any, save persons possessing extensive chemical knowledge" (Lupton, 1892(?), p. 17).

Surgical techniques would have been routine. Indeed, descriptions of Caesarean sections and of end-to-end intestinal anastomosis in cattle date back to the 17th century (Crawshey, 1636; Harward, 1673) while surgical removal of hydatid cysts from the cranium in sheep was described even earlier (Fitzherbert, 1523). Crawshey advocated the use of new milk to lubricate the arm and of silk to suture the uterus. The spaying of females, like the castration of males, has been practised since ancient times (documented by Aristotle more than 300 years B.C.; see Short, 1977), indicating a very early appreciation of the endocrine functions of the gonads. Smith (1919) cites George Turberville's 16th century description of the best time to spay bitches and also his careful observations on the effects of castration on antler growth in deer, which make the appreciation clear:

"If a deer be castrated before he had a 'head' he will never bear one; if the operation be

performed when the antlers are up, he will never shed them; or if the head is in a condition of 'velvet' it will so remain".

Smith also tells us that Turberville stated:

"This giveth us to understand that there is great virtue in the stones".

Nevertheless, endocrinology was still in its infancy in 1890 , despite the first experimental evidence of endocrine activity (again of the testis) having been presented 41 years previously (see Short, 1977). There was therefore no question of Heape inducing his rabbit donors to superovulate.

\section{Artificial insemination}

Heape's own expertise in artificial insemination has already been mentioned, although he had no need of it in his transfer experiments. The Italian, Spallanzani, had been the first to use AI except, according to Heape (1897a), for Arabs in ancient times. Spallanzani's own description of 
his success in a spaniel bitch, published in English in 1784, beautifully conveys his feelings of satisfaction:

"... sixty-two days after the injection of the seed, the bitch brought forth three lively whelps, two male and one female, resembling in colour and shape not the bitch only, but the dog also from which the seed had been taken. Thus did I succeed in fecundating this quadruped; and I can truly say, that I never received greater pleasure upon any occasion, since I first cultivated experimental philosophy" (from Marshall, 1910, pp. 181-182).

The discovery of the spermatozoa had occurred a century earlier (Ham \& Leeuwenhoek, 1677, see Needham, 1959, p. 175).

\section{Eggs and embryos}

Rabbit blastocysts have figured largely in the complex history of the discovery of the mammalian ovum which has been described by several authors, including Sarton (1931), Meyer (1939), Needham (1959), Bodemer (1971), and, most entertainingly, by Corner (1933). Regnier de Graaf had certainly found tubal and uterine blastocysts $72 \mathrm{~h}$ after mating, as he described and illustrated in De mulierum organis generationi inservientibus tractatus novus published in 1672 . A new, annotated translation of this classical work is readily available (Jocelyn \& Setchell, 1972) and shows that de Graaf made a clear distinction between 'eggs' and 'follicles', contrary to the claims of some subsequent historians. However, it is true that he believed that the egg included follicular fluid, partly because of the resemblance of sow follicles to ova in hens' ovaries, and partly because boiling human ovaries gave follicular contents "the same colour, flavour and consistency as ... the albumen of fowls' eggs"! He clearly described follicles and corpora lutea in cattle and several other species. Over 100 years were to elapse before rabbit blastocysts of the same stage were seen again, this time by William Cruikshank, a Scottish surgeon working in Chelsea in 1778. Although Cruikshank's observations reached his students each year until he published them in 1797 , they were largely ignored by the scientific community at large, for reasons described below. Prévost \& Dumas (1824) also confirmed the observations of de Graaf and Cruikshank and came close to discovering the egg proper (see Corner, 1933). The same year saw the conclusion of an early piece of 'mission orientated' research when the Göttingen Academy of Sciences awarded a prize for the discovery of the site of formation of the mammalian egg: the prize was won by a paper proving that the uterus has this role (Corner, 1933)! Three years later, the Estonian, Karl Ernst von Baer, finally found the true mammalian egg in a pet dog (von Baer, 1827). He later described the occasions and his emotions in his autobiography (von Baer, 1866; cited by Sarton, 1931 and translated by Dr G. W. Speckmann):

"Upon opening her I found a few ruptured Graafian follicles but none were near rupturing. I noticed a small yellow fleck in one of the follicles and then in many others, but always just one fleck. 'Odd!' I thought, 'What can this be?' I opened a follicle and removed the fleck with a knife into a water-filled watchglass which I took to the microscope. When I had inspected it I fell back as though struck by lightning because I saw a very small, clearly defined, yellow yolk sphere. I had to recover from this before I had the courage to look again because I feared that a ghost had deluded me. It seems strange that a sight that one has anticipated and hoped for can startle one when it materialises."

The story behind the non-acceptance of Cruikshank's confirmation of de Graaf's discovery of rabbit blastocysts is of special interest to those of us working with cattle, sheep and pigs because it involves the peculiar elongation of the blastocyst that follows hatching in these ungulates. De Graaf had not been the first to suggest that the female "testis" (ovary) produces 
eggs or embryos; Stensen (1667) and Van Horne (1668) had said as much (see Jocelyn \& Setchell, 1972, p. 200, notes 175 and 177) and the priority of observation may even belong to Langley in 1657 (see Needham, 1959, p. 163). Whatever the priorities of discovery and description, there was obvious confusion between eggs and follicles and Theodore Kerkring (1670), for example, even illustrated cow "ova" that were in fact small follicles (see Needham, 1959, p. 163 and Fig. 16). It was, of course, impossible to find any 'ovum' as big and spherical as an ovarian follicle within a week or two of mating in deer or sheep, and these were the species used in two very influential studies in the 17th and 18th centuries.

The first of these, before de Graaf, was William Harvey's careful dissection of red deer hunted by King Charles I, a study first recorded in 1651 but recently evaluated and re-enacted on film (Short, 1978). Harvey probably recovered expanded blastodermic vesicles from the uterus at about Day 20 but did not recognize the "purulent matter . . . friable and . . . inclining to yellow" as containing an embryo. This naturally led him to conclude that no trace of conception was to be found in the uterus for some days after mating and that the female contributed no "female semen" to the embryo. Harvey's education (see Corner, 1933) had made him a distant follower of Aristotle. He would therefore have expected to find a mixture of semen and menstrual blood initially forming the embryo which would later grow in the shape of a bird's egg, as in man. Finding neither male nor female contributions to an embryo soon after mating, Harvey concluded that the embryo was formed directly in the uterus under the influence of seminal "effluvium", while his sceptical audience of physicians dismissed the observations with the phrase "... that it could no waies be ....". If Harvey had used a lens in his inspections, or the horse or rabbit as his experimental animal, how different his conclusions might have been!

The second study (von Haller, 1752, after de Graaf) resulted in similar failure to find 'ova' in a series of 51 sheep and therefore supported Harvey's view and gained acceptance (helped by von Haller's pre-eminence in medicine) despite the intervening rabbit work. What was perhaps the first experimental study in reproductive biology was also ignored: Nuck (1691) showed that embryos of a bitch developed only on the ovarian side of a ligature placed on the uterine horn after copulation.

The resolution of these confusions did not really come until von Baer's discovery could be re-interpreted in terms of the cellular theory first propounded by Schwann in 1839 (see Sarton, 1931). Descriptions of the living tubal ova of sheep (Hausmann, 1840; Bischoff, 1844), dog (Bischoff, 1845) and deer (Bischoff, 1854) soon followed. The living tubal ova of our other domestic animals and of man were not described until much later: the pig by Keibel (1897) and Assheton (1898); the cat by Longley (1911); man by Allen, Pratt, Newell \& Bland (1928); the cow by Hartman, Lewis, Miller \& Swett (1931); the mare by Amoroso, Griffiths \& Hamilton (1939) or, if that report was of an old, retained, unfertilized egg (as is possible), by Hamilton \& Day (1945). The first observations of fertilization and early cleavage were made on amphibians by Newport in 1853 (Short, 1977) and actual union of mammalian gametes was demonstrated by Hertwig in 1875 (Corner, 1933).

\section{Collection, handling and transfer techniques}

In his embryo transfer papers, Heape does not describe how he obtained his tubal ova. However, his biographer J. D. Biggers (personal communication) believes that Heape could well have been responsible for a student 'laboratory manual' on rabbit embryo recovery published as an appendix to the second edition of Foster and Balfour's Elements of Embryology in 1883. Heape performed his transfers by picking up the eggs on the tip of a spear-headed needle, which sounds awkward. According to Squier (1932), Barry obtained rabbit eggs in 1839 by expressing the contents from half-inch segments of oviduct, as first suggested by his "indefatigable" fellow-Scot, Cruikshank. Barry (1843) was the first person to see spermatozoa within the ovum. Squier traces flushing techniques to Hensen, who used fixative solutions in 1876, and to Spee 
(1833), who used a $0.75 \%$ saline solution, favoured concave-bottomed glass receptacles (salt-cellars!) to hold the flushings and handled eggs with glass capillary tubes. Is it the familiar, unchanging simplicity of embryo handling techniques that allow us to identify ourselves with the early investigators and to share their excitements and disappointments? Corner (1933) certainly thought so and describes how, at times:

"I have caught myself wishing I could have sent Aristotle a little pocket magnifier, or have whispered to William Harvey that he would do well to give up studying deer and use rabbits instead".

Now we should move forward into more familiar territory to trace the developments of Heape's work and its extension into the farm species.

\section{The twentieth century}

\section{Early thoughts on applications}

The first record of transfers in this century was from Vienna in 1922, rabbits again being the experimental animals (Biedl, Peters \& Hofstätter, 1922). The success rate in that study was not only low (1 pregnancy from 70 experiments) but also doubtful, because the young were born at night and had been eaten by next morning (Dowling, 1949).

The 1920s were active years on many aspects of relevance to embryo transfer. They were the time of the establishment of the relationship between the anterior pituitary and the ovaries, of considerable developments in artificial insemination, and of initial studies in the culture of eggs in vitro. By the close of the decade, the potential advantages of exploiting these advances in livestock breeding had probably been appreciated. Writing of the work done in Marshall's Institute of Nutrition at Cambridge, Marshall \& Hammond (1946) follow a section on the advantage of artificial insemination (AI) with the following statement:

“... the first steps towards a similar extension of the reproductive powers of good genetic stock on the female side ... (were) ... begun in 1929 by G. Pincus, a visiting National Research Council fellow from Harvard University, who, following work initiated by Heape, cultivated the fertilized eggs of the rabbit outside the body and later successfully transplanted them into other does. By the use of anterior pituitary hormones ... he was able to obtain up to fifty or more fertilized eggs at one time for this purpose. These experiments have yet to be extended to farm animals, in which its possibilities are great".

This retrospective summary may have been a little condensed because Pincus (1930) did not mention superovulation of his rabbit donors and had no success with his transfers of cultured ova. He did achieve a pregnancy with 1 of 3 control (direct) transfers and cited Asdell and Hammond as obtaining $3 / 21$ successes in unpublished experiments, which may be those reported by Hammond elsewhere (Hammond, 1930, cited by Nicholas, 1933). The transfers were undertaken to test the viability of cultured embryos, and whether the practical applications alluded to in 1946 were already apparent in 1929 must remain a point for speculation. Given the dedication of Marshall and Hammond to applying science to agriculture, it seems likely that they were. Hammond's exceptional devotion to this end and his complementary ability to "... describe his work or expound his ideas to an audience of farmers or butchers with the same ease, clarity, and lack of affectation with which he would address a meeting of the Royal Society ..." is made clear in his obituary by Pomeroy (1965). However, before tracing the early uses of embryo transfer, we should consider the parallel developments that made them possible. 


\section{Gonadotrophins and superovulation}

The story of how the relationship between the pituitary gland and the gonads was elucidated is a fascinating one and has been recounted by Corner (1947), Parkes (1966), Greep (1973) and Short (1977). In the present context the induction of superovulation of animals was a very early result. As early as 1927, the year that Smith \& Engle and Zondek \& Aschheim separately demonstrated the pituitary-gonad link, Engle produced 19-29 implantations in mice induced to superovulate. Aschheim \& Zondek (1928) went on to demonstrate the presence of oestrogens and gonadotrophins in the serum and urine of pregnant women. This directly stimulated similar searches in domestic animals and the early discovery of both activities in the serum of pregnant mares by Cole \& Hart (1930) at Davis. Thus, two sources of gonadotrophin became available for use in superovulation studies. Considering the recent demonstrations of the superiority of pituitary preparations over PMSG for inducing superovulation in cattle, it is salutary to realize that similar comparisons were made, and similar conclusions reached, in the 1930s and 1940s (see Dowling, 1949). PMSG treatment was first used for therapy rather than superovulation in cattle (Hart \& Cole, 1933) and for induction of out-of-season breeding in sheep (Cole \& Miller, 1933). Russian studies with cattle (cited by Casida, Meyer, McShan \& Wisnicky, 1943) used a variety of gonadotrophins and one reported the induction of superovulation with pituitary preparations (Rumjancev, 1938). Russians were also the first to induce multiple pregnancies in sheep treated with PMSG (Loginova \& Lopyrin, 1938; Lopyrin, Loginova \& Babicev, 1940). Extensive studies in Wisconsin with pituitary extracts between 1934 and 1941 (Casida et al., 1943; Casida, Warwick \& Meyer, 1944) and wartime efforts with both PMSG and horse pituitary extracts in Britain (Parkes \& Hammond, 1940; Folley \& Malpress, 1944) firmly established their effects in both cattle and sheep and laid the groundwork for the profusion of superovulation studies that followed (reviewed by Gordon, 1975).

\section{Synchronization of oestrus}

Induction of oestrus by manual expression of the corpus luteum per rectum was a practice advocated in the first edition of Hammond's Physiology of Reproduction in the Cow (1927) and was used in some early superovulation studies. Veterinary use of rectal examinations dates back to Roman times in horses (Smith, 1919, p. 24). In cattle, it is said to have been used by the Russians for pregnancy diagnosis as early as 1815 but, in Britain at least, was considered "rather unprofessional" before the second world war (Noakes, 1979).

Synchronization of oestrus in donor and recipient in the first transfer that produced a calf was accomplished by injections of progestationally active concentrate (Willett, Black, Casida, Stone \& Buckner, 1951). Synthetic progestagens were used from later in the 1950s and luteolytic prostaglandins have been widely used in transfer work since the early 1970 s.

\section{Artificial insemination}

AI of livestock had already been put to extensive practical use in Russia by the 1930s (see Asdell, 1969). Its potential for international movement of genes was demonstrated when Arthur Walton mailed rabbit semen from Cambridge to Edinburgh in 1926, following this with successful shipment of sheep semen to Poland (Walton \& Prawochenski, 1936) and bull semen to Holland (Edwards, Walton \& Siebenga, 1938). The practice has survived longer than the term "eutelegenesis" used to describe it in 1936. The successful freezing of gametes owes something to Pincus because Parkes' interest in cryobiology, which led to the discovery of the cryoprotective action of glycerol by Polge, Smith \& Parkes in 1949, resulted from a 1942 paper by Pincus (Parkes, 1968). 


\section{Early transfers in farm animals (Table 1)}

The contribution of Pincus and Chang to embryo transfer may not be as well known as their relationship to "The Pill". Their involvement was with the Foundation of Applied Research of San Antonio, Texas. Cattle transfer work was initiated there by G. Pincus and R. Umbaugh (Chang, 1971). Umbaugh (1949) said that 750 cows had been used during the preceding 8 years, so this work in the early 1940s must have been the first in cattle and the first to be obviously geared to commercial ends. There was evidently considerable exchange of information between San Antonio and Cambridge (see Umbaugh, 1949; Dowling, 1949). M. C. Chang had been trained by Walton and Hammond in Cambridge and one of his first tasks when he came to the United States to work with Pincus in 1945 was to induce superovulation in cows (see Chang, 1971). His subsequent rabbit work included storage of embryos for some days at $10^{\circ} \mathrm{C}(1947$, 1948), the demonstration of embryotoxic factors in untreated sheep and cattle serum (1944), the definition of the need for donors and recipients to be synchronized (1950), the first long-distance shipment of embryos (back to Cambridge) with Marden (1952) and the first live births after invitro fertilization (1959). The lattermost feat has yet to be emulated for farm animals. In all these papers, and in his amusing 1971 summary of this phase of his work, Chang acknowledges the support of Gregory Pincus.

Table 1. First records of successful embryo transfers

\begin{tabular}{lll}
\hline Date & \multicolumn{1}{c}{ Species } & \multicolumn{1}{c}{ Reference } \\
\hline 1891 & Rabbit & Heape \\
1933 & Rat & Nicholas \\
1934 & Sheep & Warwick et al. \\
1934 & Goat* & Warwick et al. \\
1942 & Mouse & Fekete \& Little \\
1949 & Cow $\dagger$ & Umbaugh \\
1949 & Goat & Warwick \& Berry \\
1951 & Cow & Willett et al. \\
1951 & Pig & Kvasnickii \\
1964 & Cow (cervical) & Mutter et al. \\
1968 & Ferret & Chang \\
1974 & Horse & Oguri \& Tsutsumi \\
1976 & Baboon & Kraemer et al. \\
1978 & Man $\ddagger$ & Steptoe \& Edwards \\
1978 & Cat & Schriver \& Kraemer \\
1979 & Dog & Kinney et al. \\
\hline & * Re-insertion. & \\
\hline & $\dagger$ Aborted. &
\end{tabular}

Very few transfers seem to have been completed at San Antonio and the venture was ultimately a financial disaster. However, the Foundation did sponsor the first conference devoted to embryo transfer and its practical implications. This was held in April, 1949. Umbaugh also achieved the first 4 pregnancies with transferred embryos in cattle although they all aborted before 8 months: 2 possibly from brucellosis and 2 probably as a result of receiving 16 to 17 embryos. The first embryo transfer calf was born as a result of a co-operative study between the University of Wisconsin and the USDA (Willett et al., 1951). The Day-5 embryo had been collected at slaughter and surgically transferred via a midline incision to the horn contralateral to the corpus luteum to negate the possibility that the calf originated from the recipient's own ovum even though she had not been inseminated. The coat-colour descriptions to 
prove parentage were reminiscent of Heape's, but partial blood-typing was also used. One of the first 3 calves produced at Wisconsin spent part of its prenatal life in a pool of spilt medium on a laboratory bench —early testimony to the hardiness of the 4-cell embryo (Dr H. D. Hafs, personal communication). Embryo transfer there was obviously seen as a research tool:

"It is believed that this technique, with improvements, may be valuable in the study of certain fertility problems in cows where a question of normality of the ovum vs. normality of the genital tract is involved". (Willett et al., 1951.)

Research was also the motivation for the earlier successes in sheep and goats, which were the first in farm animals. Warwick, Berry \& Horlacher (1934), working at the A \& M College of Texas, used embryo transfer to throw light on the possibility that failure of sheep-goat hybrids might be due to the uterine environment, while Casida et al. (1944) used it in Wisconsin to test the viability of embryos produced after superovulation. In rats, too, the first transfers (at Yale) constituted an embryo viability test and established the importance of synchrony between donor and recipient (Nicholas, 1933). In mice, it was first cancer research at Bar Harbor, Maine, in 1935 (see Fekete \& Little, 1942) and then genetic work in Edinburgh (Beatty, 1951) that prompted the early transfers.

Disappointing success rates in farm animals in many laboratories after these early successes inhibited progress. Failures were related to technique, so early procedures are of interest.

\section{Collection techniques}

Embryo collection from laboratory animals was obviously most easily accomplished at slaughter and the first collections from cows (Hartman et al., 1931) and pigs (Kvasnickii, 1951) were made in the same way. Surgical methods of recovering embryos were first developed for man (Allen et al., 1928) and were used in early work with sheep and goats (Warwick et al., 1934) and cattle (Umbaugh, 1949). Collection methods from cows have undergone a curious reversal: some of the earliest methods on both sides of the Atlantic and in Japan were non-surgical (see Brand \& Drost, 1977a), but vastly superior results were obtained surgically at Cambridge by Rowson, Moor \& Lawson (1969) who built on successful methods developed on sheep in the 1950s and 1960s. L. E. A. Rowson represents a third generation of research scientists who have drawn students and co-workers from around the world to Cambridge with mushrooming influence on embryo transfer. Publication of these results coincided with the first widespread commercial use of embryo transfer and it was therefore surgical collection that was most widely used in the early 1970s, despite its obvious limitations (see Elsden, 1977). Non-surgical methods were again used from 1976, with numerous 're-discoveries' of the earliest methods. Various means of collecting eggs from relocated, and therefore more accessible, ovaries or from chronically cannulated reproductive tracts were also tried and found wanting.

\section{Culture media}

The importance of collection and culture media in embryo transfer work has been realized since the first studies on living mammalian eggs were begun in 1918 (see Hartman, 1929). C. G. Hartman (1879-1967) was a colourful giant in the field of reproduction, as had been conveyed by Biggers (1970) and a succession of Carl G. Hartman lecturers to the Society for the Study of Reproduction. He loved analogies. His first cow egg paper (Hartman, Lewis, Miller \& Swett, 1931), for example, concludes thus:

"If one wishes to visualize how small a cow's egg really is ... he should scatter a pinch of sea sand on a sheet of black paper-the smallest grain visible to the naked eye is of the order of magnitude of the cow's egg. Again, it can be readily calculated from the above dimensions that a thimble holding about $3 \mathrm{cc}$ would require pretty close to $2,000,000$ cow eggs to fill it". 
Elsewhere (1961) he describes how sufficient numbers of spermatozoa to sire the whole of the next generation of mankind would look like one-third of a stick of chewing gum. Like most of us, probably, Hartman was affected by the beauty of embryos saying (1967):

“... Patterson showed me an open armadillo uterus containing a vesicle implanted on the surface of the endometrium. I thought that vesicle about the most beautiful natural object I had ever seen and still think so, although since then I have handled a thousand opossum and rabbit and a hundred monkey vesicles".

His work in monkeys, incidentally, was inspired in part by the earlier studies of Walter Heape.

Culture techniques have been comprehensively reviewed (Foote \& Onuma, 1970; Seidel, 1977) and there is little to add in an historical context except to mention that early searches for suitable media even extended to aqueous humour (Warwick \& Berry, 1949). The fortunate discovery that the rabbit oviduct can accommodate the continued development of embryos of other species, combined with the international distribution of ex-Cambridge investigators, was intrumental in allowing long-distance transport of sheep embryos (Adams, Rowson, Hunter \& Bishop, 1961) and later horse embryos (Allen, Stewart, Trounson, Tischner \& Bielanski, 1976) before their long-term preservation in vitro was possible.

\section{Embryo conservation}

Attempts to conserve embryos for long periods at low temperatures began at the end of the second world war. Chang (1971) describes how publication of his early successes with cooled rabbit embryos at $10^{\circ} \mathrm{C}$ in $1947^{\prime \prime} \ldots$ was one of my happiest moments, and I still remember the excitement". Extension of the cooling work into farm animals has been reviewed by Whittingham (1977). Freezing work began only a few years later and Audrey Smith gave the first paper on the subject in 1952. Mouse and rat oocytes were shown to survive freezing and thawing in ovarian tissue in the 1950s and mice had been born from frozen, thawed and transplanted ovaries by 1960 . Little more was done during the 1960 s but the first survivals of frozen-thawed embryos in mice were reported by Whittingham, Leibo \& Mazur (1972) and Wilmut (1972) and in cattle by Wilmut \& Rowson (1973). The short history of freezing embryos has been told by Polge (1977) and, needless to say, developments since then are proceeding too rapidly to be reviewed historically. However, it is interesting that the Cambridge-Poland route crops up again in the first international shipment of frozen sheep embryos (Willadsen \& Tischner, 1978).

\section{Micromanipulation of embryos}

Techniques for micromanipulation of embryos have reached great degrees of sophistication in laboratory animals (see Daniel, 1978). They have been extended into farm species to produce chimaeric lambs (Tucker, Moor \& Rowson, 1974), sexed calves (Hare et al., 1976) and identical twin lambs (Willadsen, 1979) but the field is again too new to bear historical analysis.

Other modern approaches to controlling the sex ratio at birth have centred largely on separating X-and Y-bearing spermatozoa (reviewed by Hare \& Betteridge, 1978) but the older history of the subject could constitute a folkloric study in itself. Smith (1919) chronicles many ideas on the subject: in 456 B.C. it was thought that females came from the left testicle and males from the right; Pliny knew in A.D. 50 that bulls dismounted to the right after siring a male and to the left after begetting a female; the Geoponica (a work which also revealed that the double hump of the Bacterian camel was due to impregnation by a wild boar) stated that sex was determined by wind direction at the time of copulation; and George Turberville, the same man who knew ". . . there is great virtue in the stones", was also aware that, for breeding hounds, sexual intercourse after the moon has passed the full, and under Gemini and Aquarius, produces mainly males, and males "less prone to madness" at that. 


\section{Transfer techniques}

Surgical transfer methods, once Heape's spear-headed needle had given way to pipettes, have remained remarkably similar over the years and across the species, with the exception that tubal or uterine puncture is often avoided in pigs by threading rubber tubing through the oviduct. The very first pregnancy in pigs was achieved non-surgically (Kvasnickii, 1951) although the translated methodological description is vague, to say the least. Non-surgical methods were also used by Umbaugh $(1949,1951)$ but it is not clear whether any of his early cattle pregnancies were achieved in this way. The variety of techniques that were tried as non-surgical methods in cattle is intriguing: besides cervical approaches with and without uterine insufflation, they included transrectal and transvaginal methods and the use of gelatin-embedded ova attached to the ovarian ligament by barbs (see reviews by Foote \& Onuma, 1970; Brand \& Drost, 1977b). It would be easy, but unfair, to dismiss these efforts as bizarre, for we have the benefit of hindsight.

\section{The commercial era}

Consideration of the present is a reminder that this 'history' has reached a point where its demarcation from a review of current literature begins to blur. All of us are well aware of the advances that have been made over the past decade as embryo transfer has been put to use commercially on scales that dwarf all previous developmental work.

Canada was very much at the centre of the hectic early days of commercial transfer, especially in the West with Alberta Livestock Transplants being the earliest and best established company. Cambridge remained a Mecca for many aspiring transferers and transatlantic traffic was heavy. Others, convinced of the ultimate necessity for non-surgical methods, crossed the Pacific to learn from Sugie in Japan. Public interest was intense and every calf born had to be 'a first'. When the first sexed calf was born, we were surprised to be visited at the ADRI by a sceptical lady journalist from the financial bureau of the Wall Street Journal. Her presence, it turned out, was due to misinterpretation of the news that we had made an advance in "stock" improvement.

Hammond and Pincus would surely have been gratified to know that one commercial company now completes about 3000 transfers per year very close to where Umbaugh's laudable but precocious efforts foundered. They would have been pleased to see the transfer units attached to Universities, the financial support given to research by governments and similar agencies, notably the European Economic Community. They would equally have welcomed the way in which the technique has been extended to other species, to international trade, treatment of sterility, disease control and a myriad of research uses. Heape's business instincts might have been roused by the stories of fortunes made and fortunes lost; but we are still too close for perspective, and it must be for someone else one day to take up the history of embryo transfer in the 1970 s and beyond. Let up hope that we shall continue to give that author something to write about.

\section{References}

Adams, C.E., Rowson, L.E.A., Hunter, G.L. \& Bishop, G.P. (1961) Long distance transport of sheep ova. Proc. 4 th Int. Congr. Anim. Reprod. \& A.I., The Hague 2, 381-382.

Allen, E. \& Doisy, E.A. (1923) An ovarian hormone; preliminary report of its localization, extraction and partial purification, and action in test animals. $J . A m$. med. Ass. 81, 819-821.

Allen, E., Pratt, J.P., Newell, Q.U. \& Bland, L. (1928) Recovery of human ova from the uterine tubes: time of ovulation in the menstrual cycle. J. Am. med. Ass. 91, 1018-1020.
Allen, W.R., Stewart, F., Trounson, A.O., Tischner, M. \& Bielanski, W. (1976) Viability of horse embryos after storage and long distance transport in the rabbit. J. Reprod. Fert. 47, 387-390.

Amoroso, E.C., Griffiths, W.B. \& Hamilton, W.J. (1939) A living tubal ovum of the horse. Vet. Rec. 51, 168.

Aschheim, S. \& Zondèk, B. (1928) Schwangerschaftsdiagnose aus dem Harn (durch Hormonnachweiss). Klin. Wschr. 7, 8-9.

Asdell, S.A. (1969) Historical introduction. In Reproduction in Domestic Animals, 2nd edn, pp. 
1-16. Eds H. H. Cole \& P. T. Cupps. Academic Press, New York.

Assheton, R. (1898) The development of the pig during the first ten days, Q. J. microsc. Sci. 41, 329-359.

Barry, M. (1843) Spermatozoa observed within the mammiferous ovum. Phil. Trans. R. Soc. 133, 33.

Bateson, W. (1909) Mendel's Principles of Heredity. Cambridge University Press.

Beatty, R.A. (1951) Transplantation of mouse eggs. Nature, Lond. 168, 995.

Biedl, A., Peters, H. \& Hofstätter, R. (1922) Experimentelle Studien über die Einnistung und Weiterentwicklung des Eies im Uterus. $\bar{Z}$. Geburtshilfe Gynäk. 84, 59-130.

Biggers, J.D. (1970) Introduction of the first Carl G. Hartman lecturer. Biol. Reprod. 2, 1-4.

Bischoff, T.W.L. (1844) Beweis von der Begattung unabhängiger periodischer Reifung und Loslösung der Eier der Säugethiere und des Menschen als die erste Bedingung ihrer Fortpflanzung. Giessen.

Bischoff, T.L.W. (1845) Entwicklungsgeschichte des Hundeeies. Braunschweig.

Bischoff, T.L.W. (1854) Entwicklungsgeschichte des Rehes. Giessen.

Bodemer, C.W. (1971) The biology of the blastocyst in historical perspective. In The Biology of the Blastocyst, pp. 1-25. Ed. R. J. Blandau. University of Chicago Press.

Brand, A. \& Drost, M. (1977a) Embryo collection by non-surgical methods. In Embryo Transfer in Farm Animals. A Review of Techniques and Applications, pp. 16-19. Ed. K. J. Betteridge. Monograph No. 16, Agriculture Canada.

Brand, A. \& Drost, M. (1977b) Embryo transfer by non-surgical methods. In Embryo Transfer in Farm Animals. A Review of Techniques and Applications, pp. 31-34. Ed. K. J. Betteridge. Monograph No. 16, Agriculture Canada.

Casida, L.E., Meyer, R.K., MeShan, W.H. \& Wisnicky, W. (1943) Effects of pituitary gonadotropins on the ovaries and the induction of superfecundity in cattle. Am. J. vet. Res. 4, 76-94.

Casida, L.E., Warwick, E.J. \& Meyer, R.K. (1944) Survival of multiple pregnancies induced in the ewe following treatment with pituitary gonadotropins. $J$. Anim. Sci. 3, 22-28.

Chang, M.C. (1968) Reciprocal insemination and egg transfer between ferrets and mink. J. exp. Zool. 168 , $49-60$.

Chang, M.C. (1971) Experimental studies of mammalian spermatozoa and eggs. Biol. Reprod. 4, 3-15.

Cole, H.H. \& Hart, G.H. (1930) The potency of blood serum of mares in progressive stages of pregnancy in effecting the sexual maturity of the immature rat. Am.J. Physiol. 93, 57-68.

Cole, H.H. \& Miller, R.F. (1933) Artificial induction of ovulation and oestrum in the ewe during anoestrum. Am. J. Physiol. 104, 165-171.

Corner, G.W. (1933) The discovery of the mammalian ovum. In Lectures on the History of Medicine (Mayo Fdn), pp. 401-426. W. B. Saunders, Philadelphia.

Corner, G.W. (1947) The Hormones of Human Reproduction. Princeton University Press.

Corner, G.W. (1961) Foreword. In Sex and Internal
Secretions, 3rd edn. Ed. W. C. Young. Williams \& Wilkins, Baltimore.

Crawshey, J. (1636) The Countryman's Instructor. (Cited by Smith, 1919, p. 297.)

Cruikshank, W.C. (1797) Experiments in which, on the third day after impregnation, the ova of rabbits were found in the Fallopian tubes; and on the fourth day after impregnation in the uterus itself; with the first appearances of the foetus. Phil. Trans. R. Soc. 87, $197-214$

Daniel, J.C., Jr (Ed.) (1978) Methods in Mammalian Reproduction. Academic Press, New York.

Dowling, D.F. (1949) Problems of the transplantation of fertilized ova. J. agric. Sci., Camb. 39, 374-396.

Edwards, J., Walton, A. \& Siebenga, F. (1938) On exchange of bull semen between England and Holland. J. agric. Sci., Camb. 28, 501-508.

Elsden, R.P. (1977) Embryo collection by surgical methods. In Embryo Transfer in Farm Animals. A Review of Techniques and Applications, pp. 10-13. Ed. K. J. Betteridge. Monograph No. 16, Agriculture Canada.

Engle, E.T. (1927) Pregnancy following superovulation in the mouse. Proc. Soc. exp. Biol. Med. 25, 84-85.

Fekete, E. \& Little, C.C. (1942) Observations on the mammary tumor incidence of mice born from transferred ova. Cancer Res. 2, 525-530.

Fitzherbert, J. (1523) Cited by Smith, 1919, p. 129.

Folley, S.J. \& Malpress, F.H. (1944) The response of the bovine ovary to pregnant mares' serum and horse pituitary extract. Proc. $R$. Soc. B 132, 164-188.

Foote, R.H. \& Onuma, H. (1970) Superovulation, ovum collection, culture and transfer. A review. J. Dairy Sci. 53, 1681-1692.

Gordon, I. (1975) Problems and prospects in cattle egg transfer. Irish vet. $J$. 29, 21-30 and 39-62.

Greep, R.O. (1973) A vista of research on the mammalian gonadotropins. Biol. Reprod. 8, 2-10.

Hamilton, W.J. \& Day, F.T. (1945) Cleavage stages of the ova of the horse, with notes on ovulation. J. Anat. 79, $127-130$.

Hammond, J. (1927) Physiology of Reproduction in the Cow. Cambridge University Press.

Hare, W.C.D. \& Betteridge, K.J. (1978) Relationship of embryo sexing to other methods of prenatal sex determination in farm animals: a review. Theriogenology 9, 27-43.

Hare, W.C.D., Mitchell, D., Betteridge, K.J., Eaglesome, M.D. \& Randall, G.C.B. (1976) Sexing 2-week-old bovine embryos by chromosomal analysis prior to surgical transfer: preliminary methods and results. Theriogenology 5, 243-253.

Hart, G.H. \& Cole, H.H. (1933) The gonad-stimulating hormone of mare serum. Proc. 26th Ann. Meet. Am. Soc. Anim. Prod. pp. 262-268.

Hartman, C.G. (1929) How large is the mammalian egg? A review. $Q$. Rev. Biol. 4, 373-388.

Hartman, C.G. (1961) A half century of research in reproductive physiology. Fert. Steril. 12, 1-19.

Hartman, C.G. (1967) Research should spell FUN. J. Reprod. Fert., Suppl. 2, pp. 1-10.

Hartman, C.G., Lewis, W.H., Miller, F.W. \& Swett, W.W. (1931) First findings of tubal ova in the cow, together with notes on oestrus. Anat. Rec. 48, $267-275$. 
Harvey, w. (1651) Exercitationes de generatione animalium. London.

Harward, M. (1673) The Herdsman's Mate. (Cited by Smith, 1919, p. 328.)

Hausmann (1840) Ueber die Zeugung und Entstehung des wahren weiblichen Eies. Hannover. (Cited by Hartman, 1931.)

Heape, W. (1891) Preliminary note on the transplantation and growth of mammalian ova within a uterine foster-mother. Proc. R. Soc. 48, 457-458.

Heape, W. (1897a) The artificial insemination of mammals and subsequent possible fertilization or impregnation of their ova. Proc. R. Soc. 61, 52-63.

Heape, W. (1897b) Further note on the transplantation and growth of mammalian ova within a uterine foster-mother. Proc. R. Soc. 62, 178-183.

Heape, W. (1898) On the artificial insemination of mares. Veterinarian 71, 202-212.

Heape, W. (1899) Abortion, barrenness and fertility in sheep. J. Roy. Agric. Soc. Ser. III 10, 1-32.

Heape, W. (1900) The "sexual season" of mammals and the relation of the "pro-oestrum" to menstruation. $Q$. J. microsc. Sci. 44, 1-70.

Heape, W. (1905) Ovulation and degeneration of ova in the rabbit. Proc. R. Soc. B 76, 260-268.

Heape, W. (1906) The Breeding Industry. Its value to the Country, and its Needs. Cambridge University Press.

Jocelyn, H.D. \& Setchell, B.P. (1972) Regnier de Graaf on the Human Reproductive Organs. J. Reprod. Fert., Suppl. 17.

Jones, L.M. (1957) Veterinary Pharmacology and Therapeutics, pp. 124-125. Iowa State College Press, Ames.

Keibel, F. (1897) Normentafeln zur Entwicklungsgeschichte des Schweines (Sus scrofa dom.). Jena.

Kinney, G.M., Pennycook, J.W., Schiver, M.D., Templeton, J.W. \& Kraemer, D.C. (1979) Surgical collection and transfer of canine embryos. Biol. Reprod. 20, Suppl. 1, 96A.

Kraemer, D.C., Moore, G.T. \& Kramen, M.A. (1976) Baboon infant produced by embryo transfer. Science, N.Y. 192, 1246-1247.

Kvasnickii, A.V. (1951) Interbreed ova transplantations (in Russian). Soc. Zootekh. 1, 36-42. [Anim. Breed. Abstr. 19, 224.]

Loginova, N.V. \& Lopyrin, A.I. (1938) Increasing multifoetation in sheep by the action of mare pregnancy serum (in Russian). Probemy Zhivot. 10, 114-120. [Anim. Breed. Abstr. 8, 255.]

Longley, W.H. (1911) The maturation of the eggs and ovulation in domestic cat. Am.J. Anat. 12, 139-168.

Lopyrin, A.I., Loginova, N.V. \& Babicev, I.G. (1940) Field experiments on raising the proportion of multiple births in Karakul sheep (in Russian). Sov. Zootekh. 1, 82-88. [Anim. Breed. Abstr. 9, 325.]

Lupton, J.I. (1892?) The diseases and management of cattle, sheep and pigs. In Modern Practical Farriery, A Complete System of the Veterinary Art as at Present Practised at the Royal Veterinary College, London, by W.J. Miles. William Mackenzie, London.

Marshall, $\overline{\mathbf{F}} . \overline{\mathbf{H}} . \mathbf{A} . \quad(191 \overline{0})$ The Physiology of Reproduction, Ist edn. Longmans Green and Co., London.
Marshall, F.H.A. (1930) Walter Heape-1855-1929. (Obituary). Proc. R. Soc. B 106, xv-xviii.

Marshall, F.H.A. \& Hammond, J. (1946) The Science of Animal Breeding in Britain. Longmans Green and Co., London.

Meyer, A.W. (1939) The Rise of Embryology. Stanford University Press.

Mutter, L.R., Graden, A.P. \& Olds, D. (1964) Successful non-surgical bovine embryo transfer. A.I. Digest 12 , 3.

Needham, J. (1959) A History of Embryology, 2nd edn. Cambridge University Press.

Nicholas, J.S. (1933) Development of transplanted rat eggs. Proc. Soc. exp. Biol. Med. 30, 1111-1113.

Noakes, D. (1979) Reappraisal of pregnancy diagnosis. Vet. Rec. 104, 251-252.

Nuck, A. (1691) Adenographia curiosa et uteri foeminei anatome nova cum epistola ad amicum de inventis novis. Leiden. (Cited by Bodemer, 1971.)

Oguri, N. \& Tsutsumi, Y. (1974) Non-surgical egg transfer in mares. J. Reprod. Fert. 41, 313-320.

Parkes, A.S. (1949) Obituary: F. H. A. Marshall. J. Endocr. 6, 1-5.

Parkes, A.S. (1966) The rise of reproductive endocrinology. J. Endocr. 34, xix-xxxii.

Parkes, A.S. (1968) Gregory Pincus, as I knew him-an appreciation. J. Reprod. Fert. 17, 231-234.

Parkes, A.S. \& Hammond, J. (1940) Induction of fertility by the injections of gonadotrophic preparations. Vet. Rec. 52, 540-542.

Pincus, G. (1930) Observations on the living eggs of the rabbit. Proc. R. Soc. B 107, 132-167.

Polge, C. (1977) The freezing of mammalian embryos: perspectives and possibilities (and discussion). In The Freezing of Mammalian Embryos (Ciba Fdn. Symp. No. 52), pp. 3-18. Eds K. Elliott \& J. Whelan. Elsevier-Excerpta Medica-North Holland, Amsterdam.

Polge, C., Smith, A.U. \& Parkes, A.S. (1949) Revival of spermatozoa after vitrification and dehydration at low temperatures. Nature, Lond. 164, 666.

Pomeroy, R.W. (1965) Sir John Hammond, C.B.E., F.R.S. (Obituary). Nature, Lond. 206, 135-136.

Prévost, J.L. \& Dumas, J.B.A. (1824) De la génération dans les mammifères, et des premiers indices de développement de l'embryon. Ann. Sci. Nat. 3, 113-138.

Rowson, L.E.A., Moor, R.M. \& Lawson, R.A.S. (1969) Fertility following egg transfer in the cow: effect of method, medium and synchronization of oestrus. $J$. Reprod. Fert. 18, 517-523.

Rumjancev, N.V. (1938) The influence of total prepituitary preparation on the genitalia of the cow (in Russian). Usp. Zootekh. Nauk 5, 73-85. [Anim. Breed. Abstr. 8, 130.]

Sarton, G. (1931) The discovery of the mammalian egg and the foundation of modern embryology. Isis 16, 315-378.

Schriver, M.D. \& Kraemer, D.C. (1978) Embryo transfer in the domestic feline. Am. Ass. Lab. Anim. Sci. Publ. 78-4, p. 12.

Seidel, G.E., Jr (1977) Short-term maintenance and culture of embryos. In Embryo Transfer in Farm Animals. A Review of Techniques and Applications, 
pp. 20-24. Ed. K. J. Betteridge. Monograph No. 16, Agriculture Canada.

Short, R.V. (1977) The discovery of the ovaries. In The Ovary, 2nd edn, Vol. I, pp. 1-39. Eds S. Zuckermann \& B. J. Weir. Academic Press, New York.

Short, R.V. (1978) Harvey's conception: 'De generatione animalium', 1651. In Developments in Cardiovascular Medicine, pp. 353-363. Eds C. J. Dickinson \& J. Marks. MTP Press Ltd, Lancaster.

Smith, A.U. (1952) Behaviour of fertilized rabbit eggs exposed to glycerol and to low temperatures. Nature, Lond. 170, 374-375.

Smith, F. (1919) The Early History of Veterinary Literature and Its British Development, Vol. 1. Baillière, Tindall \& Cox, London.

Smith, P.E. \& Engle, E.T. (1927) Experimental evidence reporting the role of the anterior pituitary in the development and regulation of the genital system. Am.J. Anat. 40, 159-217.

Squier, R.R. (1932) The living egg and early stages of its development in the guinea-pig. Contr. Embryol. Carnegie Instn 23, 225-230.

Steptoe, P.C. \& Edwards, R.G. (1978) Birth after reimplantation of a human embryo. Lancet it, 366 .

Tucker, E.M., Moor, R.M. \& Rowson, L.E.A. (1974) Tetraparental sheep chimaeras induced by blastomere transplantation. Changes in blood type with age. Immunology 26, 613-621.

Umbaugh, R.E. (1949) Superovulation and ovum transfer in cattle. Am.J. vet. Res. 10, 295-305.

Umbaugh, R.E. (1951) Superovulation and ovum transfer in cattle. Fert. Steril. 2, 243-252.

von Baer, K.E. (1827) De ovi mammalium et hominis genesi. Leipzig. (Facsimile in Sarton, 1931.)

von Haller, A. (1746-52) Disputationum anatomicarum selectarum. (Cited by Bodemer, 1971 and Sarton, 1931.)

Walton, A. (1926) Preservation of mammalian spermatozoa. Nature, Lond. 118, 265.
Walton, A. \& Prawochenski, R. (1936) An experiment in eutelegenesis. $J$. Hered. 27, 341-344.

Warwick, B.L. \& Berry, R.O. (1949) Inter-generic and intra-specific embryo transfers. $J$. Hered. 40, 297303.

Warwick, B.L., Berry, R.O. \& Horlacher, W.R. (1934) Results of mating rams to Angora female goats. Proc. 27th Ann. Meet. Am. Soc. Anim. Prod. pp. 225-227.

Whittingham, D.G. (1977) Low temperature preservation of embryos. In Embryo Transfer in Farm Animals. $A$ Review of Techniques and Applications, pp. 50-53. Ed. K. J. Betteridge. Monograph No. 16, Agriculture Canada.

Whittingham, D.G., Leibo, S.P. \& Mazur, P. (1972) Survival of mouse embryos frozen to $-196^{\circ} \mathrm{C}$ and $-269^{\circ} \mathrm{C}$. Science, N.Y. 178, 411-414.

Willadsen, S.M. (1979) A method for culture of micromanipulated sheep embryos and its use to produce monozygotic twins. Nature, Lond. 227, 298-300.

Willadsen, S.M. \& Tischner, M. (1978) Successful long-distance transport by car of sheep embryos stored in liquid nitrogen. Bull. Acad. pol. Sci. Cl. II. Sér. Sci. Biol. 26, 725-726.

Willett, E.L., Black, W.G., Casida, L.E., Stone, W.H. \& Buckner, P.J. (1951) Successful transplantation of a fertilized bovine ovum. Science, N.Y. 113, 247.

Wilmut, I. (1972) Effect of cooling rate, warming rate, cryoprotective agent and stage of development on survival of mouse embryos during freezing and thawing. Life Sci. 11, 1071-1079.

Wilmut, I. \& Rowson, L.E.A. (1973) The successful low temperature preservation of mouse and cow embryos. J. Reprod. Fert. 33, 352-353.

Zondek, B. \& Aschheim, S. (1927) Das Hormone des hypophysenvorderlappens. Klin. Wschr. 6, 248-252.

Received 28 April 1980 